\title{
Tumor Budding in Colorectal Carcinomas
}

\section{Kolorektal Karsinomlarda Tümör Tomurcuklanması}

\author{
Sevda SERT BEKTAŞ, Gülsün INAN MAMAK, İbrahim Metin ÇíRiş, Kemal Kürşat BOZKURT, \\ Nilgün KAPUCUOĞLU
}

Department of Pathology, Süleyman Demirel University, Faculty of Medicine, ISPARTA, TURKEY

\section{ABSTRACT}

Objective: In colorectal carcinomas, tumor budding has been defined as the presence of isolated single tumor cells or small cell clusters in the stroma at the invasive tumor margin. In this study, the relationship between tumor budding density at the invasive tumor margin and pathological parameters is investigated.

Material and Method: Haematoxylin and eosin stained slides of 73 cases with colorectal carcinoma were retrospectively evaluated for the presence and intensity of tumor budding by 2 observers. After the specimens were assessed, the highest density of tumor budding area was counted in a microscopic field of $\mathrm{x} 200$. Cases were separated into 2 groups according to tumor budding density as low grade $(<10)$ and high grade $(\geq 10)$. The relationship of these groups with depth of tumor invasion, histological grade, vascular invasion and lymph node involvement was investigated.

Results: Of the 73 colorectal carcinoma cases, 33 (45.2\%) had low and $40(54.8 \%)$ had high grade tumor budding density, respectively. There was a statistically significant relationship between high grade tumor budding density and histological grade $(\mathrm{p}=0.042)$, lymph node involvement $(\mathrm{p}=0.0001)$ and vascular invasion $(\mathrm{p}=0.0034)$.

Conclusion: High grade tumor budding density is associated with aggressive phenotypical features in colorectal carcinoma.

Key Words: Colorectal neoplasms, Neoplasm invasion, Lymph node, Metastasis

\section{INTRODUCTION}

Tumor budding is a peculiar feature that is observed in colorectal adenocarcinomas. In colorectal carcinomas, 'tumor budding' has been defined as the presence of isolated single neoplastic cells or small cell clusters of up to four cells in the stroma at the invasive tumor margin (1-8). It was first reported by Imai (9). Although he used the term 'sprouting' instead of 'budding' he was the one who showed

Received : 01.06.2010

Accepted : 06.09.2010

\section{ÖZ}

Amaç: Kolorektal karsinomlarda tümör tomurcuklanması, invaziv tümör komşuluğundaki stromada bulunan izole tümör hücreleri ya da küçük tümöral hücre kümeleri olarak tanımlanmaktadır. Bu çalışmada kolorektal karsinomlarda invaziv tümör komşuluğundaki stromada bulunan tümör tomurcuklanması yoğunluğunun patolojik özelliklerle ilişkisi araştırılmıştır.

Gereç ve Yöntem: Retrospektif olarak, kolorektal karsinomlu 73 olguya ait hematoksilen-eozin boyalı preparatlar tümör tomurcuklanması varlığı ve yoğunluğunun tespit edilmesi amaciyla 2 gözlemci tarafından değerlendirilmiştir. Preparatlar tekrar değerlendirildikten sonra tümör tomurcuklanmaları, en yoğun oldukları alan tespit edilerek x200 büyütme alanında sayılmıştır. Olgular, tümör tomurcuklanması yoğunluğu 10'dan az olanlar düşük dereceli, 10 ve üzeri olanlar yüksek dereceli olmak üzere 2 gruba ayrılmıştır. Bu grupların tümörün invazyon derinliği, histolojik derecesi, lenf nodu tutulumu ve vasküler invazyon gibi patolojik özelliklerle ilişkisi araştırılmıştır.

Bulgular: Kolorektal karsinomlu 73 olgunun 33'ünde (\%45,2) düşük, 40 ’ında $(\% 54,8)$ yüksek dereceli tümör tomurcuklanması yoğunluğu tespit edilmiştir. Yüksek dereceli tümör tomurcuklanması yoğunluğu ile histolojik derece $(\mathrm{p}=0.042)$, lenf nodu tutulumu $(\mathrm{p}=0,0001)$ ve vasküler invazyon $(\mathrm{p}=0,0034)$ arasında istatistiksel olarak anlamlı ilişki saptanmıştır.

Sonuç: Yüksek dereceli tümör tomurcuklanması yoğunluğu kolorektal karsinomlarda agresif fenotipik özelliklerle ilişkilidir.

Anahtar Sözcükler: Kolorektal tümörler, Neoplazi invazyonu, Lenf nodları, Metastaz

that tumors with this feature have more aggressive features (9). Morodomi et al. used the term 'tumor budding' first in 1989 (10).

Since Dukes' original classification, staging systems, which consider parameters; lymph-node involvement of the tumor and depth of mural invasion, are in use to predict the long-term survival following surgical resection in colorectal cancers (3). Dukes' staging system comprises

Correspondence: Kemal Kürşat BOZKURT

Department of Pathology, Süleyman Demirel University, Faculty of Medicine, ISPARTA, TURKEY

E-mail: kemalkbozkurt@hotmail.com Phone: +90 2462112934 
two parameters: tumor penetration depth and lymph node involvement (11). The TNM classification of International Union Against Cancer (UICC), the most widely used standardized pathological staging system, considers depth of invasion, lymph node involvement and distant metastasis as parameters (12). Efforts have been made to improve the prognostic prediction of these systems because of the observation of different clinical outcome between the patients with same Dukes' or TNM stage, which is usually observed in colorectal adenocarcinomas. This ambiguity may be explained by the fact that these standardized pathological staging systems do not reflect biological behavior of carcinoma exactly, which may correlate with tumor aggressiveness and risk of recurrence.

There are reports which determines the association of tumor budding at the invasive tumor margin and tumor behavior (3-8). Dedifferentiation and dissociation of cancer cells has been reported to be the first event of invasion and metastasis in experimental studies. Tumor budding is the morphologic expression of this event (6). It has also been shown that it is an independent and a reproducible prognostic factor (1). In addition, tumor buds can be appreciated in conventional haematoxylin and eosin stained (H\&E) slides by careful observation (3).

Correlation between tumor budding and lymph node metastasis has already been shown by several studies in the past few years (2-4). Today it is widely accepted that tumor budding is an important predictor for recurrence and poor prognosis in advanced colorectal cancers. Because tumor budding is associated with prognosis, Association of Directors of Anatomic and Surgical Pathology (ADASP) recommended that budding should be included in staging systems and it should be scored as present or absent (8). In this study the relationship between the intensity of tumor budding at the invasive tumor margin and pathological parameters is investigated.

\section{MATERIAL and METHODS}

Our study comprised 73 patients who were diagnosed as colorectal adenocarcinoma and underwent surgery in Süleyman Demirel University School of Medicine between 2003 and 2007. The primary tumor was located in the colon in $50(68.5 \%)$ cases and in the rectum in $23(31.5 \%)$ cases. Tumors were resected with right hemicolectomy in 12 cases, with transvers hemicolectomy in 11 cases, with left hemicolectomy in 15 cases, with sigmoidectomy in 12 cases and with low anterior resection in 23 cases. None of the operative specimens had positive surgical margins. In macroscopic examination 4 to 10 samples were obtained from each tumor specimen. The pathological staging of all cases was performed according to the 6th edition of UICC/ TNM classification system (13).
Retrospectively, paraffin embedded and $\mathrm{H} \& \mathrm{E}$ stained slides of 73 surgically resected colorectal carcinoma cases were reevaluated simultaneously by 2 observers to assess the presence and intensity of tumor budding in the invasive tumor margin. For these tumors, morphological features of known prognostic importance such as tumor diameter, depth of invasion, histological type, histological grade, extramural vascular invasion and lymph node involvement were recorded from the pathology reports. None of the patients had familial polyposis coli, hereditary nonpolyposis colorectal carcinoma, multiple colorectal carcinoma or inflammatory bowel disease.

From each resected specimen all the slides were reviewed. After the specimens were assessed, one slide containing the highest density of tumor budding was selected for evaluation by using a Nikon Optiphot- 2 microscope. For the detection of the area that contained the highest tumor budding density, at least 10 areas were assessed in each resection specimen. Tumor buddings were counted in the area of highest tumor budding density within a microscopic field of $\times 200$ in this slide. An isolated single cancer cell and/ or a cluster composed of up to 4 neoplastic cells were defined as budding foci (Figure 1). After counting the highest density of tumor budding in selected slide of each case, the tumor budding density was classified into 2 groups as low grade (less than 10 tumor buds) and high grade (10 or more tumor buds) as Shinto et al., Ueno et al., and Choi et al. did in their studies to investigate the correlation of tumor budding density with depth of tumor invasion, histological grade, vascular invasion and lymph node involvement (Figure 2A,B) (5-7).

The chi-square test and Fisher's exact test were used to determine the relationship between categorized variables. A p-value of $<0.05$ was considered statistically significant.

\section{RESULTS}

Of the 73 patients, 41 (56.2\%) were male and $32(43.8 \%)$ were female. The mean age was 63.7 years (range 34-93 years). In these 73 cases, the histological grade of the tumors were well differentiated in $37(50.7 \%)$ cases, moderately differentiated in 28 (38.4\%) cases and poorly differentiated in $8(10.9 \%)$ cases. There was lymph node involvement in $41(56.2 \%)$ cases and no lymph node involvement in 32 (43.8\%) cases. Vascular invasion was present in 27 (37\%) cases, 46 (63\%) cases were without vascular invasion. Of the 73 patients, $64(87.7 \%)$ tumors were pT3, 7 (9.6\%) tumors were pT2, $1(1.35 \%)$ tumor was pT1 and $1(1.35 \%)$ tumor was pTis. Clinicopathological characteristics of 73 patients are presented in Table I.

In 33 (45.2\%) cases tumor budding density was lower than 10 and in $40(54.8 \%)$ cases there were 10 or more tumor 


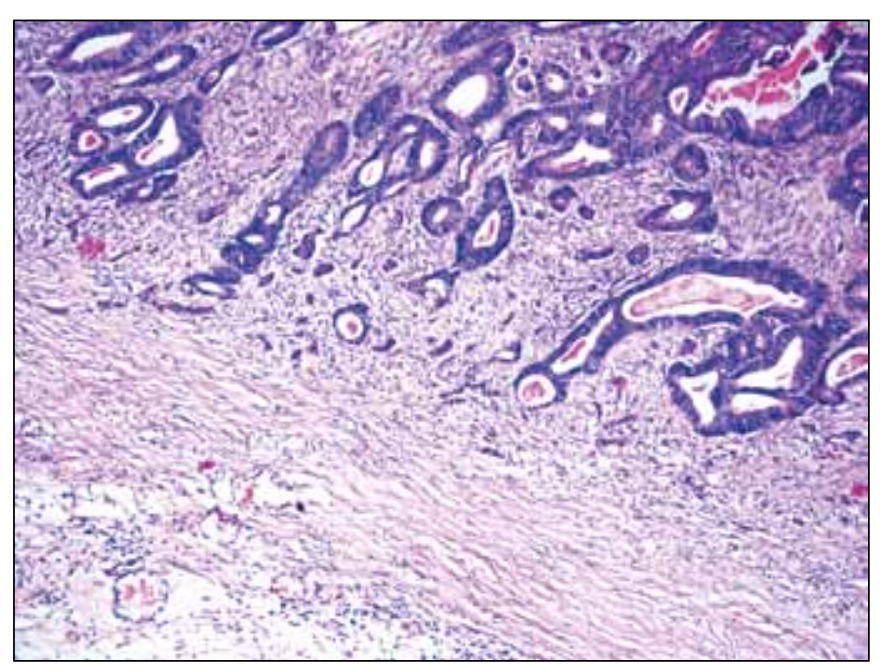

Figure 1: Tumor buddings at the invasive margin of a colorectal adenocarcinoma (H\&E, x100).
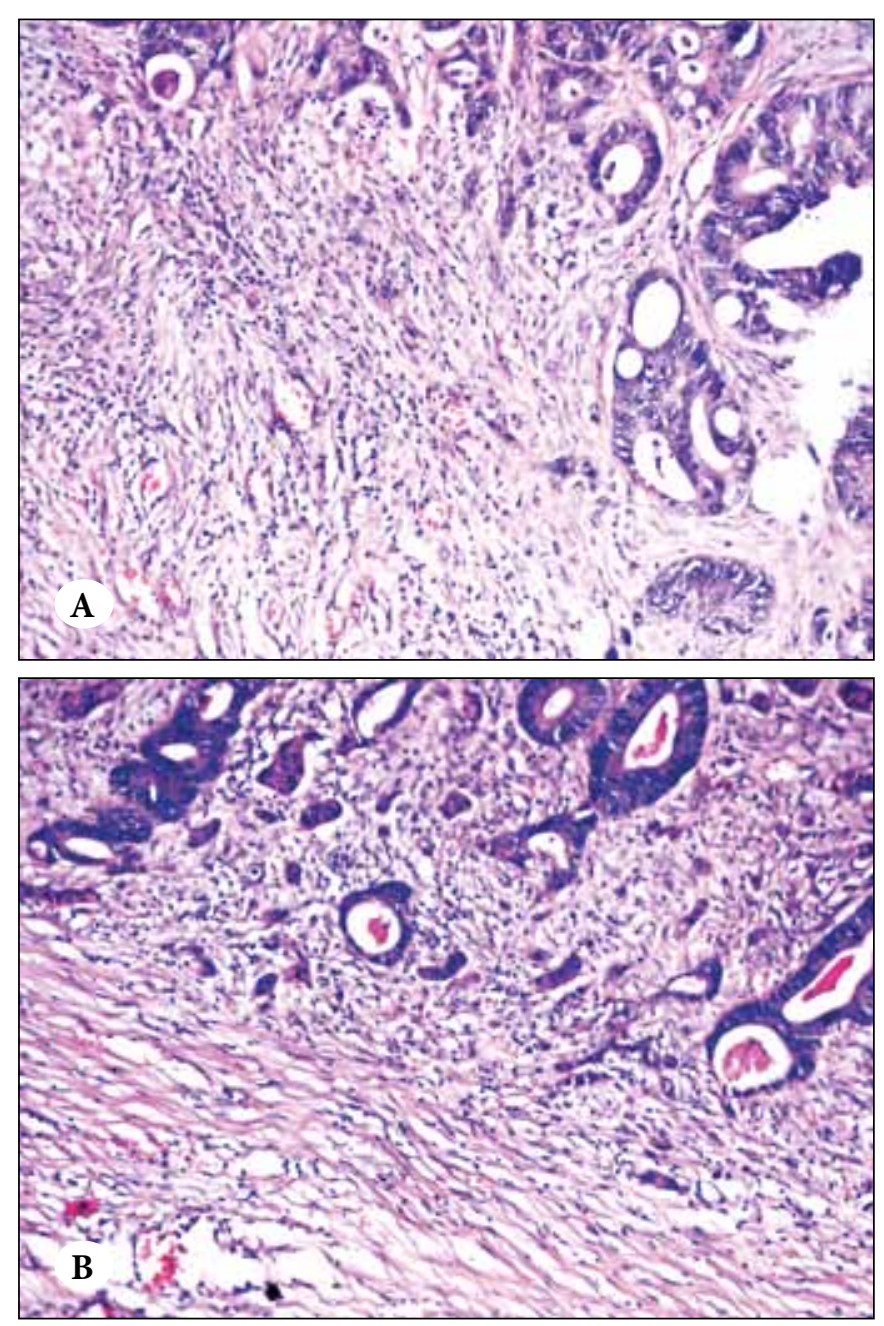

Figure 2: (A) Low grade (H\&E, x200), (B) and high grade tumor budding density (H\&E, x200).
Table I: Clinicopathologic characteristics of 73 colorectal carcinoma patients

\begin{tabular}{|l|c|}
\hline Variable & $\begin{array}{c}\text { Number of patients } \\
(\mathbf{N}=73)\end{array}$ \\
\hline Mean age & 63.7 \\
\hline Sex & $41(56.2 \%)$ \\
Male & $32(43.8 \%)$ \\
\hline Histological grade & \\
Well differentiated & $37(50.7 \%)$ \\
Moderately differentiated & $28(38.4 \%)$ \\
Poorly differentiated & $8(10.9 \%)$ \\
\hline Depth of tumor invasion & $1(1.35 \%)$ \\
pTis & $1(1.35 \%)$ \\
pT1 & $7(9.6 \%)$ \\
pT2 & $64(87.7 \%)$ \\
pT3 & \\
\hline Lymph node involvement & $32(43.8 \%)$ \\
pN0 (0) & $22(30.2 \%)$ \\
pN1 (1-3) & $19(26 \%)$ \\
pN2 ( $\geq 4)$ & \\
\hline Vascular invasion & $46(63 \%)$ \\
Absent & $27(37 \%)$ \\
Present & \\
\hline
\end{tabular}

buddings. In the cases whose tumor budding density was $<10$, histological grade was well differentiated in $21(63.6 \%)$ cases, moderately differentiated in $10(30.3 \%)$ cases and poorly differentiated in $2(6.1 \%)$ cases. In the cases that tumor budding density was $\geq 10$, histological grade was well differentiated in 16 (40\%) cases, moderately differentiated in $18(45 \%)$ cases and poorly differentiated in $6(15 \%)$ cases.

Among the 33 cases with low grade tumor budding density there was no lymph node involvement in 23 (69.7\%) cases, while $10(30.3 \%)$ cases were with lymph node involvement. Of 10 cases, 1 to 3 lymph nodes were involved in 5 (15.15\%) and 4 or more lymph nodes were involved in the remaining 5 (15.15\%). Among the 40 cases with high grade tumor budding density there was not lymph node involvement in $9(22.5 \%)$ cases and there was lymph node involvement in $31(77.5 \%)$ cases. Among these 31 cases 1 to 3 lymph nodes were involved in $17(42.5 \%)$ cases and 4 or more lymph nodes involved in $14(35 \%)$ cases.

There was a statistically significant relationship between high grade tumor budding density and lymph node metastasis $(\mathrm{p}=0.0001)$. In addition, tumors with 1 to 3 $(\mathrm{pN} 1)(\mathrm{p}=0.001)$ and 4 or more $(\mathrm{pN} 2)(\mathrm{p}=0.003)$ lymph node metastasis had significantly higher tumor budding 
density than nonmetastatic group (pN0). However, there was no statistically significant difference between $\mathrm{pN} 1$ and pN2 tumors for tumor budding density.

In the group with a tumor budding density of $<10,27(81.8 \%)$ cases were with vascular invasion, while $6(18.2 \%)$ cases had no vascular invasion. In the high grade tumor budding density group $(\geq 10), 19(47.5 \%)$ cases were without vascular invasion and 21 (52.5\%) cases had vascular invasion.

In low grade tumor budding density group 29 (87.9\%) tumors were pT3, $2(6.1 \%)$ tumors were pT2, 1 (3\%) tumor was pT1 and $1(3 \%)$ tumor was pTis according to their depth of invasion. In the high grade tumor budding density group $35(87.5 \%)$ tumors were pT3 and 5 (12.5\%) tumors were $\mathrm{pT} 2$.

There was a statistically significant association between high grade tumor budding density and histological grade $(\mathrm{p}=0.042)$ and vascular invasion $(\mathrm{p}=0.0034)$. However, there was no statistically significant relationship between the depth of tumor invasion and tumor budding density $(\mathrm{p}=0.4475)$. The association of clinicopathological parameters and tumor budding density is presented in Table II.

\section{DISCUSSION}

Lymph node metastasis is one of the most important prognostic factors in colorectal carcinomas (14). The depth of submucosal invasion, tumor grade at the deepest invasive portion and existence of lymphovascular invasion are predictive markers for lymph node metastasis of colorectal carcinoma (15). It has been reported that tumor budding that represents dedifferentiated histology at the invasive margin is useful in predicting lymph node metastasis or hematogenous metastasis (16). In this regard tumor budding has been shown to reflect the biological aggressiveness of colorectal cancers $(15,17)$. It seems to be the first histological event of invasion, metastasis and poor prognosis. It is a histological feature that appears at invasive front of the lesion rather than at the predominant tumor site. As the biologically most relevant area with the malignant potential of the tumor is the area of invasive front in colorectal carcinoma, tumor budding might reflect the biological aggressiveness of the tumor itself $(15,17)$. The results of our study provides evidence about the prognostic value of tumor budding.

According to our results, high grade tumor budding density is significantly associated with higher histological grade, vascular invasion and presence of lymph node metastasis in colorectal carcinomas. Our results are concordant with the results of Morodomi et al., Goldstein et al., and Okuyama et al., who reported that tumor budding is associated with pathological parameters including venous invasion and lymph node metastasis in colorectal carcinomas $(10,18,19)$. These findings support the idea that tumor buds originate from the cells which have higher malignant potential. Although there was a significant relationship with lymph

Table II: Association of clinicopathological parameters and tumor budding density

\begin{tabular}{|c|c|c|c|}
\hline \multirow[b]{2}{*}{ Parameters } & \multicolumn{3}{|c|}{ Tumor budding density } \\
\hline & $<10$ tumor buds $(\mathrm{N}=33)$ & $\geq 10$ tumor buds $(\mathrm{N}=40)$ & p value \\
\hline $\begin{array}{l}\text { Histological grade } \\
\text { Well }(\mathrm{N}=37) \\
\text { Moderate }(\mathrm{N}=28) \\
\text { Poor }(\mathrm{N}=8)\end{array}$ & $\begin{array}{c}21(63.6 \%) \\
10(30.3 \%) \\
2(6.1 \%)\end{array}$ & $\begin{array}{r}16(40 \%) \\
18(45 \%) \\
6(15 \%)\end{array}$ & $0.042^{\star}$ \\
\hline $\begin{array}{l}\text { Vascular invasion } \\
\text { Absent }(\mathrm{N}=46) \\
\text { Present }(\mathrm{N}=27)\end{array}$ & $\begin{array}{r}27(81.8 \%) \\
6(18.2 \%)\end{array}$ & $\begin{array}{l}19(47.5 \%) \\
21(52.5 \%)\end{array}$ & $0.0034^{\star}$ \\
\hline $\begin{array}{c}\text { Lymph node metastasis } \\
\text { Absent }(\mathrm{N}=32) \\
\text { Present }(\mathrm{N}=41)\end{array}$ & $\begin{array}{l}23(69.7 \%) \\
10(30.3 \%)\end{array}$ & $\begin{array}{r}9(22.5 \%) \\
31(77.5 \%)\end{array}$ & $0.0001^{\star}$ \\
\hline $\begin{array}{l}\text { Depth of tumor invasion } \\
\text { pTis }(\mathrm{N}=1) \\
\text { pT1 }(\mathrm{N}=1) \\
\text { pT2 }(\mathrm{N}=7) \\
\text { pT3 }(\mathrm{N}=64)\end{array}$ & $\begin{array}{c}1(3 \%) \\
1(3 \%) \\
2(6.1 \%) \\
29(87.9 \%)\end{array}$ & $\begin{array}{c}0(0 \%) \\
0(0 \%) \\
5(12.5 \%) \\
35(87.5 \%)\end{array}$ & 0.4475 \\
\hline
\end{tabular}

*: Statistically significant $(\mathrm{p}<0.05)$ 
node involvement and high grade tumor budding density there was no association between the number of involved lymph nodes and tumor budding density according to our results. In addition to this, our results revealed that depth of tumor invasion is not associated with tumor budding density in contrast to the study of Ueno et al. (20).

The importance of tumor budding and the mechanism of its occurrence is also stated by a group of molecular studies $(16,21)$. The loss of both glandular differentiation and cell cohesion that gives rise to dissociated elements probably is a crucial event in the development of invasion and metastatic properties in colorectal carcinomas (21). This would be consistent with the important and independent adverse prognostic significance of tumor budding. In addition tumor budding was found to be correlated with less favourable outcome $(7,22)$.

In the present study, histological grade, lymph node involvement and vascular invasion were significantly associated with high grade tumor budding density, but in some studies a significant correlation was found between budding and lymph node involvement even when budding regarded only as positive or negative (15). Most of the studies in the literature were performed to investigate the prognostic importance of tumor budding considering them only as absent or present. All the tumors included in our study had at least 2 tumor buddings at the invasive margin. Because of this feature we could not investigate the importance of buddings considering them as absent or present. Our study is performed to investigate the intensity of tumor budding and its relationship with aggressive histopathological features. We separated the cases into two groups as high grade and low grade tumor budding density. Tumors with less than 10 tumor buds considered as low grade group and tumors with 10 or more tumor buds considered as high grade group just as Shinto et al., Ueno et al., and Choi et al. did in their studies (5-7). The intensity of tumor budding was also investigated by grouping the cases as mild $(<5)$, moderate (5-9) and marked $(\geq 10)(23)$. We also used this classification in our study too, but our results were not statistically significant.

Although there are reports which advise to use immunohistochemistry to detect tumor budding, in our study we evaluated the tumor buds in conventional $\mathrm{H} \& \mathrm{E}$ stained slides $(2,24)$. The minimum requirements for an ideal prognostic parameter are, first, that the grading should be reproducible and widely available with quality control, and second, that the grading has substantial predictive value beyond recognized prognostic systems (23). Tumor budding can be identified and graded easily with the use of light microscopy which makes it simple and applicable in routine pathological settings.
In conclusion the results of our study reveal that high grade tumor budding density is associated with aggressive phenotypical features in colorectal carcinoma and it can be used as a practical and reliable parameter to identify higher malignancy potential. Although we admit that, the number of patients analyzed in the present study is not large enough to draw a definite conclusion, we recommend the examination of budding in the routine pathological diagnosis of colorectal carcinomas at least as present or absent. We suggest tumor budding as a risk factor for an adverse outcome in invasive colorectal carcinoma. Evaluating tumor budding can be helpful in improving the staging systems and treatment approach and it can be an additional pathological parameter which helps determining tumor behavior.

\section{REFERENCES}

1. Shinto E, Baker K, Tsuda H, Mochizuki H, Ueno H, Matsubara O, Foulkes WD, Jass JR: Tumor buds show reduced expression of Laminin-5 Gamma 2 chain in DNA mismatch repair deficient colorectal cancer. Dis Colon Rectum 2006, 49:1193-1202

2. Kazama S, Watanabe T, Ajioka Y, Kanazawa T, Nagawa $H$ : Tumor budding at the deepest invasive margin correlates with lymph node metastasis in submucosal colorectal cancer detected by anticytokeratin antibody Cam 5.2. Br J Cancer 2006, 94: 293-298

3. Prall F: Tumor budding in colorectal carcinoma. Histopathology 2007, 50:151-162

4. Losi L, Ponti G, Grego DC, Marino M, Rossi G, Pedroni M, Benatti P, Roncucci L, de Leon MP: Prognostic significance of histological features and biological parameters in stage I (pT1 and pT2) colorectal adenocarcinoma. Pathol Res Pract 2006, 202: 663-670

5. Shinto E, Machizuki E, Ueno H, Matsubara O, Jass JR: A novel classification of tumor budding in colorectal cancer based on the presence of cytoplasmic pseudo-fragments around budding foci. Histopathology 2005, 47:25-31

6. Ueno H, Price AB, Wilkinson KH, Jass JR, Mochizuki H, Talbot IC: A new prognostic staging system for rectal cancer. Ann Surg 2004, 240:832-839

7. Choi HJ, Park KJ, Shin JS, Roh MS, Kwon HC, Lee HS: Tumor budding as a prognostic marker in stage III rectal carcinoma. Int J Colorectal Dis 2007, 22:863-868

8. Jass JR, O'Brien MJ, Riddell RH, Snover DC: Association of Directors of Anatomic and Surgical Pathology (ADASP). Recommendations for the reporting of surgically resected specimens of colorectal carcinoma. Virchows Arch 2007, 450: $1-13$

9. Imai T: The growth of human carcinoma. A morphological analysis. Fukuoka Igaku Zasshi 1954, 45:13-43

10. Morodomi T, Isomoto H, Shirouzu K, Kakegawa K, Irie K, Morimatsu M: An index for estimating the probability of lymph node metastasis in rectal cancers. Lymph node metastasis and the histopathology of actively invasive regions of cancer. Cancer 1989, 63: 539-543 
11. 1. Dukes C: The classification of cancer of the rectum. J Pathol Bacteriol 1932, 3S:323-332

12. Sobin LH: TNM: Principles, history and relation to other prognostic factors. Cancer 2001, 91:1589-1592

13. Greene FL, Page DL, Flening D, Firtz A, Batch M, Haller DG, Morrow M: American Joint Committee on Cancer (AJCC) Cancer Staging Manual. 6th ed., Springer-Verlag, New York, 2002

14. Park SY, Choe G, Lee HS, Jung SY, Park JG, Kim WH: Tumor budding as an indicator isolated tumor cells in lymph nodes from patients with node negative colorectal cancer. Dis Colon Rectum 2005, 48:292-302

15. Kaneko I, Tanaka S, Oka S, Kawamura T, Hiyama T, Ito M, Yoshihara M, Shimamoto F, Chayama K: Lymphatic vessel density at the site of deepest penetration as a predictor of lymph node metastasis in submucosal colorectal cancer. Dis Colon Rectum 2007, 50:13-21

16. Masaki T, Matsuoka H, Sugiyama H, Abe N, Izumisato $Y$, Sakamoto A, Atomi $Y$ : Laminin $5 \nvdash 2$ chain expression as a possible determinant of tumor aggressiveness in T1 colorectal carcinomas. Dig Dis Sci 2003, 48:272-278

17. Kanazawa H, Mitomi H, Nishiyama Y, Kishimoto I, Fukui N, Nakamura T, Watanabe M: Tumor budding at invasive margins and outcome in colorectal cancer. Colorectal Dis 2008, 10:41-47

18. Goldstein NS, Hart J: Histologic features associated with lymph node metastasis in stage $\mathrm{T} 1$ and superficial $\mathrm{T} 2$ rectal adenocarcinomas in abdominoperineal resection specimens. Identifying a subset of patients for whom treatment with adjuvant therapy or completion abdominoperineal resection should be considered after local excision.. Am J Clin Pathol 1999, 111:51-58
19. Okuyama T, Oya M, Ishikawa H: Budding as a risk factor for lymph node metastasis in pT1 or pT2 well-differentiated colorectal adenocarcinoma. Dis Colon Rectum 2002, 45: 628-634

20. Ueno H, Mochizuki H, Shinto E, Hashiguchi Y, Hase K, Talbot IC: Histological indices in biopsy specimens for estimating the probability of extended local spread in rectal cancer. Cancer 2002, 94:2882-2891

21. Jass JR, Barker M, Fraser L, Walsh MD, Whitehall VLJ, Gabrielli B, Young J, Leggett BA: APC mutation and tumor budding in colorectal cancer. J Clin Pathol 2003, 56:69-73

22. Okuyama T, Oya M, Yamaguchi M: Budding (sprouting) as a useful prognostic marker in colorectal mucinous carcinoma. Jap J Clin Oncol 2002, 32:412-416

23. Ueno H, Murphy J, Jass JR, Mochizuki H, Talbot IC: Tumour budding as an index to estimate the potential of aggressiveness in rectal cancer. Histopathology 2002, 40:127-132

24. Kaneko I, Tanaka S, Oka S, Yoshida S, Hiyama T, Arihiro K, Shimamoto F, Chayama K: Immunohistochemical molecular markers as a predictors of curability of endoscopically resected submucosal colorectal cancer. World J Gastroenterol 2007, 13 : 3829-3835 